\title{
Ingenol Mebutate Gel after Cryotherapy of Actinic Keratosis: When can I Start the Topical Treatment?
}

\author{
Jose Manuel AD*, Maria RR, Jose Lauis AM and Fernando de MM \\ ${ }^{1}$ Department of Dermatology, Complejo Hospital ario University, Spain
}

*Corresponding author: Jose Manuel AD, Department of Dermatology, Complejo Hospital, C/ Hermanos Falcó 3702006 Albacete, Spain, E-mail: jmazana@sescam.jccm.es

\section{Research Article}

Volume 2 Issue 1

Received Date: February 23, 2017

Published Date: March 24, 2017

DOI: $10.23880 /$ cdoaj16000118

\section{Abstract}

Actinic keratosis (AK) is a common dermatological disorder on sun-exposed skin. Its premalignant condition is widely known; therefore both treatment and protection from sunlight are needed to prevent malignant transformation. Field and lesion- targeted therapies can be combined to search a synergistic effect. Here we report our experience with cryotherapy and ingenolmebutate used sequentially, without rest interval between both treatments.

Keywords: Actinic keratosis; Therapy; Ingenolmebutate; Cryotherapy

\section{Introduction}

Actinic keratoses (AKs) are photo-induced intraepidermic keratinocytic neoplasms ${ }^{1}$. In current practice, AKs are a frequent reason for consultation². There is a risk of progression to invasive squamous cell carcinoma, although some lesions can regress spontaneously [1-3]. Therapy of AKs may be targeted to individual lesions or to the field of cancerization [4-6] concept introduced by Slaughter in 1953 to designate an area of subclinical changes in the periphery of visible AK lesions [7]. There are various therapeutic options for AK, both physical and topical treatments; the treatment selected will depend on the characteristics of the lesion (number, location, grade of hyperkeratosis), and both the doctor and the patient's preferences. There is also the possibility of using combination therapies.

We present ten patients with AK streamed sequentially with cryotherapy and ingenol mebutate. The interval between both treatments is an important clue.

\section{Methods}

We included ten consecutive patients diagnosed with five to ten AKs of any type within a $25 \mathrm{~cm}^{2}$ area and treated with cryotherapy plus ingenol mebutate ; cryotherapy was applied to all AKS with an intermittent spray technique (two cycles, freeze time of 20 seconds with a 5 seconds rest interval and 2-4 mm margin of freeze around the AK) followed the same night by two (lesions located in trunk or extremities) or three (lesions located in head) once -daily applications of 0.05 or 0.015 ingenol gel respectively.

The AK diagnosis was made clinically, and only in cases of doubt a biopsy for histological examination was performed (size $>1 \mathrm{~cm}$, AK hypertrophic, bleeding, rapid expansion or pain on palpation).

They were assessed for safety on days 4 and 15 and for efficacy (complete clearance, defined as no clinically visible AKs in the treatment area, or reduction of number of AKs) at baseline and on days 60 and 365 . 
All patients provided written informed consent.

\section{Results}

The study included ten patients, 9 men and 1 woman (median age 73 years, range $65-82$ ). Two of them had a history of non melanoma skin cancer other than AK (squamous cell carcinoma, basal cell carcinoma); 9 of 10 patients had a history of recurrent AKs and prior treatment with cryotherapy (9), topical imiquimod (2) or ingenol (1), as immunotherapy.

The diagnosis was clinical in all patients except in two (patients 2 and 5): the lesions were determined to be AK by histopathological analysis of a sample obtained by one (patient 1) or three (patient 2) punch biopsies.

All of them received the sequential treatment with cryotherapy plus ingenol mebutate as described above.
After the treatment, AK lesions counts were reduced between $75-100 \%$ in 8 patients; the response was maintained in 7 of 8 after 1 year (Figure 1). All the patients experimented mild to moderate local skin reactions which developed on days 2 or 3 of treatment, and these reactions lasted for two weeks. The grade of these reactions was evaluated according to a pre-specified scale. All of them received treatment with topic fatidic acid twice a day for two weeks.

In two patients, persistent lesions on days 15 and 60 were identified (Figure 2). Lesions were located on the scalp. The histopathological study confirmed the presence of squamous cell carcinoma; surgical radical excision was indicated.

Data was collected retrospectively and was summarized in Table 1.

\begin{tabular}{|c|c|c|c|c|c|c|c|}
\hline $\begin{array}{c}\text { Patient No } \\
\text { Gender/age } \\
\text { (yrs) }\end{array}$ & $\begin{array}{c}\text { AK } \\
\text { Treatment } \\
\text { History }\end{array}$ & $\begin{array}{c}\text { Prior AK } \\
\text { Treatment }\end{array}$ & $\begin{array}{l}\text { NMSC } \\
\text { History }\end{array}$ & $\begin{array}{c}\text { AK } \\
\text { Location }\end{array}$ & $\begin{array}{c}\text { Biopsy } \\
/ / \\
\text { Result }\end{array}$ & $\begin{array}{c}\text { AK status } \\
\text { post- } \\
\text { sequential } \\
\text { therapy (day } \\
60 \text { ) }\end{array}$ & $\begin{array}{c}\text { AK status } \\
\text { post- } \\
\text { sequential } \\
\text { therapy (day } \\
365 \text { ) }\end{array}$ \\
\hline 1.-Male / 65 & Yes & $\mathrm{Cr}$ & & Scalp & Yes/AK & $>75 \%$ clear. & $>75 \%$ clear \\
\hline 2.-Male / 82 & Yes & $\mathrm{Cr}, \mathrm{Im}$ & SCC & Scalp & $\begin{array}{c}\text { Yes/ } \\
\text { AK }\end{array}$ & Persistent* & \\
\hline 3.-Male / 73 & Yes & $\mathrm{Cr}$ & & Face & & $>75 \%$ clear & $>75 \%$ clear \\
\hline 4.-Female / 70 & Yes & $\mathrm{Cr}$ & & Hand & & $>75 \%$ clear & \\
\hline 5.-Male / 79 & Yes & $\mathrm{Cr}$, In & & Scalp & & Persistent* & \\
\hline 6.-Male / 72 & Yes & $\mathrm{Cr}$ & BCC & Face & & $>75 \%$ clear & $>75 \%$ clear \\
\hline 7.-Male / 66 & No & -- & & Face & & $>75 \%$ clear & $>75 \%$ clear \\
\hline 8.-Male / 72 & Yes & $\mathrm{Cr}, \mathrm{Im}$ & & Scalp & & $>75 \%$ clear & $>75 \%$ clear \\
\hline 9.-Male / 78 & Yes & $\mathrm{Cr}$ & & Face & & $>75 \%$ clear & >75\%clear \\
\hline 10.-Male /73 & Yes & $\mathrm{Cr}$ & & Face & & $>75 \%$ clear & $>75 \%$ clear \\
\hline
\end{tabular}

Table 1: Patient demographics, baseline disease and efficacy results.

Abbreviations: AK: Actinic keratosis; BBC: Basal cell carcinoma; Clear. Clearance; Cr: Cryotherapy; Im: Imiquimod; In: Ingenol; NMSC: No melanoma skin cancer; yr: years.

*Histopathology evaluation of biopsy samples of persistent lesions: squamous cell carcinoma. 


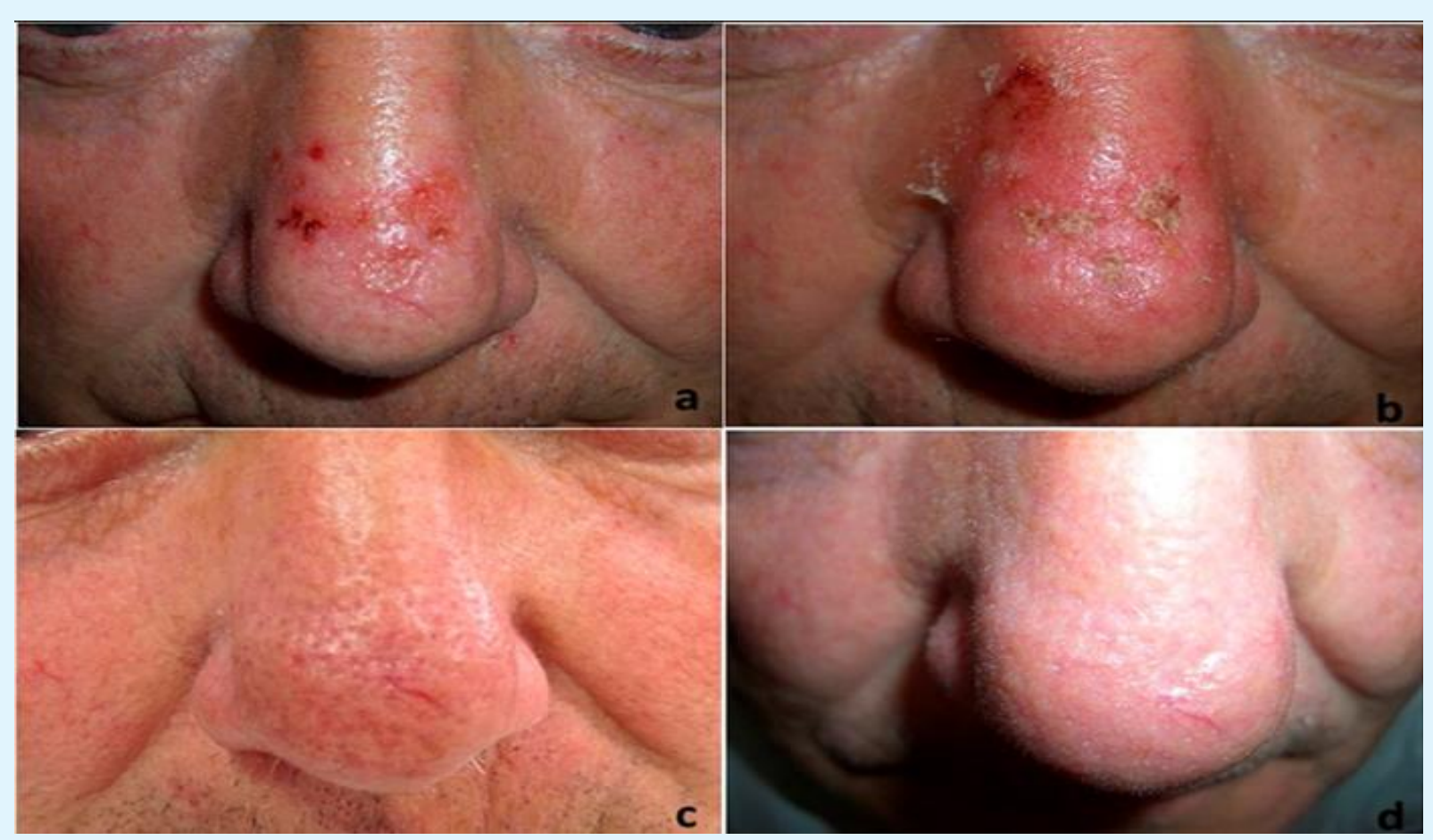

Figure 1: Patient 7. a. Pre-treatment. b. Day 4: Mild local skin reaction. c. Day 60: Complete clearance. d. Day 365 : Sustained clearance.

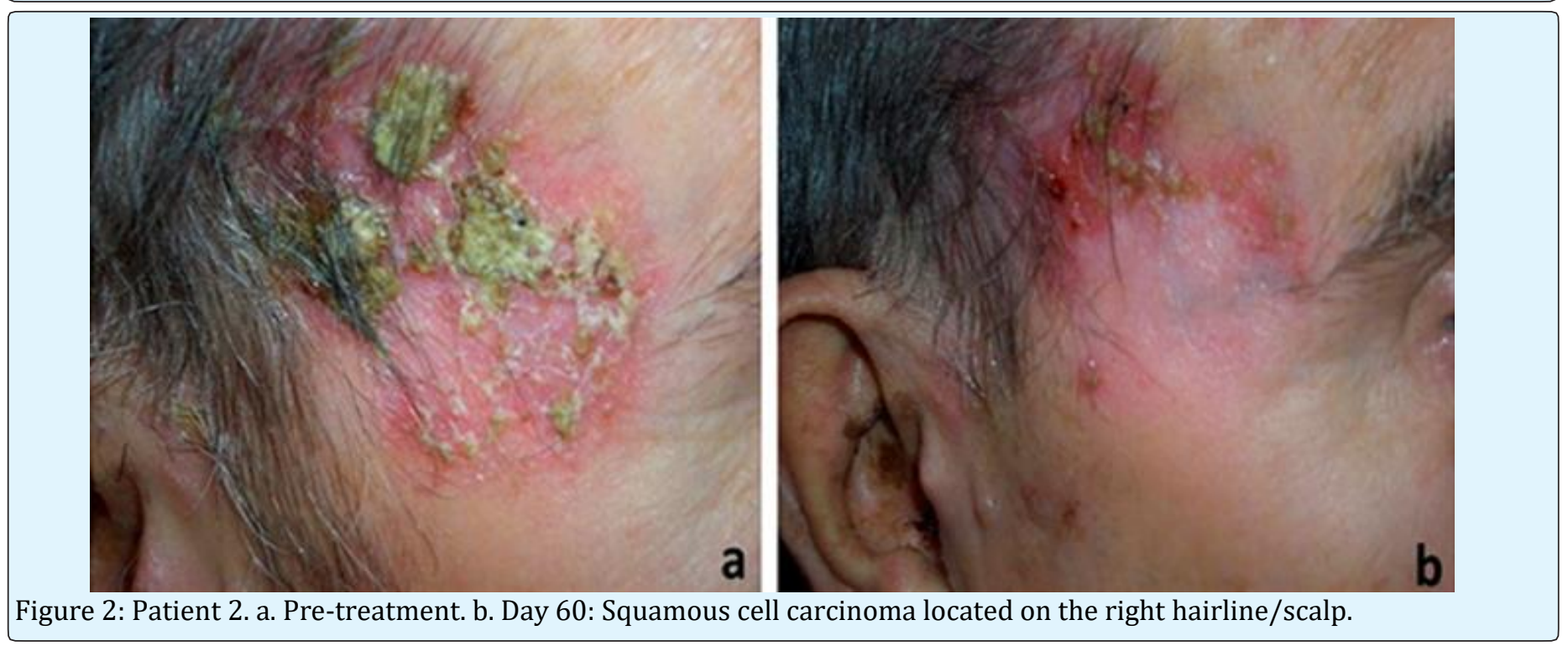

\section{Discussion}

AKs are a common reason for consultation [2]. They are lesions induced by chronic sun exposure and there is risk of evolving to squamous cell carcinoma [1,3]. Treatment options include: lesion-directed therapies, directed to destroy a single AK lesion and field-directed treatment options aimed at the destruction of latent, subclinical and clinical AKs lesions within a field of chronic sun damaged skin [4-6]. 
Cryotherapy is one of the most widely used lesiondirected therapies but it has a high rate of recurrence; in addition, there is no standardized approach to technique, duration, frequency or number of cycles. Ingenol is a novel topical agent for the field-therapy of nonhyperkeratosis non-hypertrophic AK; its main advantage is the short duration of application (2 or 3 days) [9].

The AK therapies have been combined with the belief that the synergistic effects of the treatments would enhance efficacy [10]. So, the combined therapy cryotherapy plus ingenol could increase the efficacy of the treatments applied in not combination form. Nevertheless in the pilot study, all patients received cryotherapy followed, three weeks later by ingenol ${ }^{11}$. In our study ingenol was applied on the same day as cryotherapy was performed; the skin injury induced by cryotherapy potentiates absorption of ingenol and could increase efficacy, as it has been hypothesized when cryotherapy is combined with other topical treatments [12]. Previous studies have demonstrated that pretreatment of skin with ablative laser is an effective option to enhance the inflammatory response to ingenol because the laser-exposure alters the bio distribution of the drug [13-14]. Cryotherapy could produce the same effect when it is performed on the same day the treatment with ingenol starts.

As it has been indicated in previous studies, reducing the burden of AK with a combination of interventions may help to identify persistent lesions that require further evaluation [15]. These lesions may have been preexisting, but in patient 2 a punch biopsy was informed as AK. In any case, combined therapy reduced the number of $\mathrm{AK}$ around and it increased the possibility of recognition of these suspicious lesions.

The tolerability was excellent, without severe local skin reactions or systemic adverse events. The mean $( \pm \mathrm{SD})$ maximum composite local-skin response score for patients treated with ingenol after cryotherapy was 9, $7 \pm 3$, 2; this score is similar to which is collected when the drug issued in monotherapy [9].

The limitations of this study are those of retrospective studies, the lack of controls and the limited number of patients.

In conclusion, we have presented our experience with combined therapy, cryotherapy plus ingenol. The ingenol treatment was started on the same day as cryotherapy was performed. Although more studies are needed, the efficacy of combined treatment with this scheme could be superior to any treatment alone with good tolerability and this sequential treatment might be indicated in some problematic cases.

\section{References}

1. James C, Crawford RI, Martinka M, Marks R, Actinic keratosis, et al. (2006) World Health Organization Classification of Tumors. Pathology \&Genetics. Skin Tumors. IARC Press, pp. 30-33.

2. Taberner R, Nadal C, Llambrich A, Vila A, Torné I (2010) Motivos de consulta dermatológicos en la población inmigrante y española del área de salud del Hospital Son Llàtzer (Mallorca). Actas Dermosifiliogr 101: 323-329.

3. Werner RN, Sammain A, Erdmann R, Hartmann V, Stockfleth E, et al. (2013) The natural history of actinic keratosis: a systematic review. Br J Dermatol 169(3): 502-518.

4. Stockfleth E, Ferrándiz C, Grob JJ, Leigh I, Pehamberger $\mathrm{H}$, et al (2008) Development of a treatment algorithm for actinic keratoses: A European consensus. Eur J Dermatol 18(6): 651-659.

5. Ferrándiz C, Fonseca E, García A, Guillén C Belinchón (2014) Adaptación española de la Guía europea para la evaluación y tratamiento de la queratosis actínica. Actas Dermosifiliogr 105(4): 378-393.

6. Dréno B, Amici JM, Basset-Seguin N, Cribier B, Claudel JP, et al. (2014) Management of actinic keratosis: a practical report and treatment algorithm from AKTeam (TM) expert clinicians. J Eur Acad Dermatol Venereol 28(9): 1141-1149.

7. Braakhuis BJ, Tabor MP, Kummer JA, Leemans CR, Braken-hoff RH (2003) A genetic explanation of Slaughter's concept of field cancerization: Evidence and clinical implications. Cancer Res 63(8): 17271730 .

8. Rosen R, Marmur E, Anderson L, Welburn P, Katsamas J (2014) A new, objective, quantitative scale for measuring local skin responses following topical actinic keratosis therapy with ingenolmebutate. Dermatol Ther 4(2): 207-219.

9. Lebwohl M, Swanson N, Anderson LL, Melgaard A, Xu $\mathrm{Z}$, et al. (2012) Ingenolmebutate gel for actinic keratosis. N Engl J Med 366(11): 1010-1019. 


\section{Clinical Dermatology Open Access Journal}

10. Werner RN, Stockfleth E, Connolly SM, Corrie O, Erdman R, et al. (2015) Evidence and consensusbased (S3) Guidelines for the Treatment of Actinic Keratosis-International League of Dermatological Societies in cooperation with the European Dermatology Forum - Short version. J Eur Acad Dermatol Venereol 29(11): 2069-2079.

11. Berman B, Goldenberg G, Hanke Wet, Tyring SK, Skon $\mathrm{T}$, et al. (2014) Efficacy and safety of ingenolmebutate $0.015 \%$ gel 3 weeks after cryosurgery of actinic keratosis: 11-week results. J Drugs Dermatol 13(2): 154-160.

12. Goldenberg G, Linkner RV, Singer G, Frankel A (2013) An investigator-initiated study to assess the safety and efficacy of imiquimod $3.75 \%$ cream when used after cryotherapy in the treatment of hypertrophic actinic keratosis on dorsal hands and forearms. J Clin Aesthet Dermatol 6(2): 36-43.
13. Erlendsson AM, Taudorf EH, Eriksson AH, Haak CS, Pasch U, et al. (2015) Ablative fractional laser alters bio distribution of ingenolmebutate in the skin. Arch Dermatol Res 307(6): 515-522.

14. Braun SA, Hevezi P, Homey B, Gerber PA (2015) Laser-assisted drug delivery: Enhanced response to ingenolmebutate after ablative fractional laser treatment. J Am Acad Dermatol 72(2): 364-365.

15. Bettencourt MS (2015) Effect of field treatment of actinic keratosis with ingenolmebutate gel on the identification of lesions for biopsy. J Drugs Dermatol 14(8): 813-818. 